\title{
Austerity's Effect on English Civil Justice
}

\author{
John Sorabji*
}

\begin{abstract}
This article considers the effect of austerity-induced public spending cuts on the English civil justice system. In doing so it initially examines two fundamental changes engendered by the effect austerity has had on civil court fees and legal aid: first, a challenge to the traditional commitment in English procedure to adversarial process, and a concomitant increase in inquisitorial or investigative processes; and secondly, the growth in use of unqualified individuals to act as advocates in court for individual litigants who are unable to afford legal representation. It then turns to consider what, if any, effect austerity has had on simplified processes available in English civil procedure.
\end{abstract}

Keywords: Austerity, court fees and legal aid, adversarial and inquisitorial process, McKenzie Friends, simplified process

\section{Introduction}

Austerity, which is to say the pursuit of a policy of public spending cuts by government, is an important issue in England and Wales (England) and has been since, at least, the 2010 general election. ${ }^{1}$ It arose as a consequence of the 2007 financial crisis and, most pertinently, the recapitalisation of the UK banking sector by the government in 2008. Since that time public sector spending has been subject to regular scrutiny by government in pursuit of both economic and political aims, i.e., in order to eliminate the structural deficit in public spending, stimulate the economy, maintain confidence in the UK's ability to meet its debt obligations, ${ }^{2}$ and politically, as an aspect of a commitment to neoliberal-

* DPhil, Senior Fellow, UCL Judicial Institute, University College, London, email: j.sorabji@ucl.ac.uk.

1. It is outwith the ambit of this article to consider the background, doctrinal underpinnings, or potential consequences of public sector spending reductions, for a discussion see $M$. Blyth, Austerity - The History of a Dangerous Idea (2013); D. Grimshaw and J. Rubery, Reinforcing Neoliberalism: Crisis and Austerity in the UK, in S. Lehndorff (ed.), A Triumph of Failed Ideas: European Models of Capitalism in the Crisis (2012).

2. See, for instance, Centre for Local Economic Strategies, Austerity Uncovered (2014), available at <https://www.tuc.org.uk/sites/default/ files/TUC\%20Final\%20Report\%20Dec'14_1.pdf> (last accessed, 15 November 2015), at 13; R. Skidelsky, George Osborne's Cunning Plan, The Spectator (29 April 2015).

3. Grimshaw and Rubery, above n. 1. ism, ${ }^{3}$ to create a smaller State. ${ }^{4}$ There is no reason to believe that this will change as a consequence of the 2015 general election and every reason to believe it will continue; ${ }^{5}$ further reductions in public spending of between $25 \%$ and $40 \%$ are highly likely post -2015 . $^{6}$ Government scrutiny of public expenditure has led to significant reductions in public sector funding; freezes on public sector pay; and a reduction in overall employment in the public sector. ${ }^{7}$ The justice system has not been exempt. Spending cuts have resulted in rationalisation of the court estate, reductions in court service staff numbers, improved efficiency in court service administration in order to reduce costs, and a significant reduction to legal aid provision. ${ }^{8}$ Further such reductions, both those announced prior to the general election and additional ones determined following the election, are planned during 2015. In respect of the former, an $8.75 \%$ reduction in legal aid will take effect after June 2015. ${ }^{~}$ In respect of the latter, HM Treasury has required the Ministry of Justice to reduce its expenditure by $£ 249$ million; a reduction that follows one of $£ 500$ million imposed in $2014 .{ }^{10}$ This article looks at a number of ways in which austerity has, and has not, affected the civil justice system. First, it considers two areas where austerity, in the form of changes to civil legal aid and civil court fees, is having a real impact: England's historic commitment to adversarial process,

4. See, for instance, D. Cameron M.P., P.M., Lord Mayor's Banquet Speech, 11 November 2013, available at: <https://www.gov.uk/ government/speeches/lord-mayors-banquet-2013-prime-ministersspeech> (last accessed, 15 November 2015).

5. J. van Reenen, Austerity: Growth Costs and Post-Election Plans (2015), available at: <http://cep.lse.ac.uk/pubs/download/EA020.pdf> (last accessed, 15 November 2015), at 5; R. Crawford, C. Emmerson, S. Keynes \& G. Tetlow, Post-Election Austerity: Parties' Plans Compared, 2015, available at: <http://www.ifs.org.uk/uploads/publications/bns/ BN170.pdf > (last accessed, 15 November 2015).

6. HM Treasury, Spending Review (2015), at 7.

7. See D. Grimshaw, S. Marino \& J. Rubery, Public Sector Pay and Procurement in the UK, 2012, available at: <https://research.mbs.ac.uk/ european-employment/Portals/0/docs/UK-national\%20report.pdf> (last accessed, 15 November 2015), esp. at 11, for figures relating to the Ministry of Justice.

8. See Ministry of Justice and C. Grayling L.C., Press Release, Reform of the Courts and Tribunals (28 March 2014), ‘HM Courts \& Tribunals Service will deliver a programme of reform to meet the needs and expectations of the 21st century at a lower cost to the public, with a one-off investment to deliver savings in excess of $£ 100$ million per year by 2019/20', available at: <https://www.gov.uk/government/news/ chris-grayling-reform-of-the-courts-and-tribunals> (last accessed, 15 November 2015).

9. S. Vara M.P. (the Parliamentary Under-Secretary of State for Courts and Legal Aid), Ministerial Written Statement: Legal Aid (HCWS22, 10 June 2015).

10. C. Smith, MoJ Hit with further $£ 249 m$ of CUTS, Law Gazette (4 June 2015). 
and the growing use of non-lawyers to provide legal assistance for litigants. In this regard there is a discernible and, by English standards, radical trend, and one that may recast the nature of English civil justice significantly. Secondly, it considers two areas, which have recently undergone reform: the English small claims process and the form of mediation related to it, small claims mediation. These areas could have undergone reform as a consequence of austerity. They could, for instance, have been made available to a wider range of cases in order to combat the consequences of civil legal aid cuts. What reform there was cannot, however, properly be attributed to reductions in public spending. Nor could such reforms have counteracted the effects of austerity in any event.

\section{Civil Court Fees, Civil Legal Aid, Questioning the Fundamentals}

This section is divided into two parts. The first considers changes since 2007 to civil court fees and their potential consequences. The second considers changes to civil legal aid over the same period and how they have called into question fundamental aspects of the English adversarial system of civil justice.

\subsection{Civil Fees}

Historically, the English civil justice system was funded from general taxation with a subsidy paid by court users through court fees. In 1982 the, then, government rejected this approach. The historic approach was replaced with one that required the system to be fully funded through court fees. ${ }^{11}$ General taxation would only be used to make up any funding shortfall; i.e., the taxpayer would subsidise court users. ${ }^{12}$ The rationale for this reform was the belief that the civil justice system simply provides a service for consumers who should be expected to pay for it. ${ }^{13}$ In practice this has meant the State has had to pay a significant subsidy each year, as court fees have never been sufficient to meet their purpose. From 2011 to 2013 the funding shortfall required the State to provide approximately $f_{,} 110-125$ million annually by way of subsidy. ${ }^{14}$ Since the shift in approach, the government has repeatedly and unsuccessfully attemp-

11. Ministry of Justice, Court Fees - Proposals for Reform (Cm8751, 2013), at 4 and 9, per S. Vara M.P., 'For many years [now], the civil and family courts have operated under the principle that those who use the courts should pay the full cost of the service they receive.'

12. See H. Brooke, Should the Civil Courts be Unified? (2008), at $29 \mathrm{ff} . ;$ M. Zander, The State of Justice (2000), at 39 for a discussion.

13. H. Genn, Judging Civil Justice (2010); R. Dingwall and E. Cloatre, Vanishing Trials?: An English Perspective, 7 Journal of Dispute Resolution 51, at 67 (2006).

14. Ministry of Justice, (Cm8751, 2013), at 11-12. Also see Judiciary of England and Wales, The Response of the Senior Judiciary to the Ministry of Justice Consultation Paper Court Fees: Proposals for Reform (Cm8751) (2014), at 2. ted to reduce and thereby to eliminate the State's annual subsidy. ${ }^{15}$

The financial crisis and its consequences brought this need into sharp focus. As part of the government requirement to reduce public spending, the Ministry of Justice was required to reduce its budget by over a third from 2010 to $2016 .{ }^{16}$ This had consequences for the civil courts. As the Justice Minister, Shailesh Vara M.P., explained, in the context of reform proposals in 2013,

...the courts must be properly financed so that they have the resources they need to deliver their services, as well as the funds they need to invest in improving them...But we can't ignore the economy either. This government made deficit reduction our top priority. We have taken some tough decisions, and the signs of recovery are there for all to see. Yet there is still more to do to bring public spending into line with what we can afford. The courts cannot be immune from that, and the cost to the taxpayer must fall... ${ }^{17}$

The taxpayer subsidy to the civil justice system thus had to be eliminated in order to enable the Ministry to play its part in securing an overall reduction in its, and the government's, budget. ${ }^{18}$ This was to be achieved in a number of ways.

First, court fees were to be increased in order to ensure that court users paid cost price for the service they received. Secondly, some court users would be required to subsidise others. They would do this by paying 'enhanced fees', i.e., fees above cost. ${ }^{19}$ The rationale for this innovation was to ensure that the Ministry could, finally, ensure that the civil courts were entirely selffunding. It was to enable the State to remove any remaining present and future taxpayer liability to fund the civil justice system. ${ }^{20}$

Taken together these two reforms, the latter of which was effected through primary legislation in $2014,{ }^{21}$ were anticipated to do two things: first, increase fee income by $£ 105$ million per annum; and secondly, via the use of enhanced fees, bring in further, additional, income of

15. See, for instance, Department of Constitutional Affairs, Civil Court Fees (CP10/2004); Ministry of Justice, Civil Court Fees (CP5/2007); Ministry of Justice, Civil Court Fees 2008 (CP31/2008); Ministry of Justice, Fees in the High Court and Court of Appeal Civil Division (CP15/2011).

16. Ministry of Justice, $(\mathrm{Cm} 8751,2013)$ at 6 , 'the government has made reducing the fiscal deficit a top priority, in order to set the economy on course for growth. Under the terms of its Spending Review settlements of 2010 and 2013, the Ministry of Justice is committed to reducing its budget by over a third by $2015 / 16$. The courts, and those who use them, must make a contribution to reducing public spending.'

17. Ministry of Justice $(\mathrm{Cm} 8751,2013)$, at 4 , and see $\mathrm{n} .7$.

18. The majority of the subsidy arises because civil court fees are, themselves, used to subsidise fee remissions for impecunious users of the family court system, i.e., the government subsidises the civil courts, which in turn subsidise the family justice system: see above n. 14, at 3-4.

19. Ministry of Justice $(\mathrm{Cm} 8751,2013)$, at 4 , and see n. 7 .

20. Ministry of Justice $(\mathrm{Cm} 8751,2013)$, at $27 \mathrm{ff}$. And by extension to remove the taxpayer from having to fund the family justice system.

21. Anti-social Behaviour, Crime and Policing Act 2014, s180, and see Ministry of Justice (Cm8751, 2013), at 28 
£,190 million per annum. ${ }^{22}$ They were to do so by, for instance, increasing fees for money claims of $f, 5,000$ to $£ 15,000$ by $81 \%$ and for judicial review applications by $216 \% .^{23}$ Issue fees for some high value cases were to increase by $576 \% .^{24}$ Yet further fee increases, via enhanced fees, were proposed in 2015 in order to generate additional income of $£ 55$ million. The rationale for this further increase was to assist the Ministry in meeting further spending reduction targets by enabling it to eliminate its liability to bear the cost of fee remissions in civil $_{\text {cases. }}{ }^{25}$ In other words enhanced fees were, amongst other things, to enable the Ministry to move its, the States', responsibility for securing access to justice for the impecunious to court users. ${ }^{26}$ Rather than the taxpayer subsidise the impecunious, wealthy litigants would be required to do so. Apart from enhanced fee increases, which as at June 2015 had not yet been introduced, the various fee increases came into effect in 2014 and 2015. ${ }^{27}$ Further increases are expected in $2016 .^{28}$ The exact consequences of these reforms, which as noted are not yet fully implemented, remain unclear. Those that are in force have not been in force long enough to produce empirical data concerning the impact on litigants and on claims being issued, although they have produced concern amongst the legal community generally. ${ }^{29}$ In terms of anticipated impact two points can be made.

First, the government concluded that there would be no real detriment to litigants, such that the increase would reduce rates of issue, i.e., the increases would have no

22. Ministry of Justice $(\mathrm{Cm} 8751,2013)$ at 45 ; for a discussion see Judiciary of England and Wales, (2014) ibid., at $4 \mathrm{ff}$.

23. Civil Justice Council, Response to Ministry of Justice Consultation Paper Court Fees: Proposals for Reform (2013), at 1.

24. See Lord Pannick, debate on Civil Proceedings and Family Proceedings Fees (Amendment) Order 2015, (Hansard, 4 March 2015: Column 310 ), 'If you want to sue for between $£ 10,000$ and $£ 200,000$, you will need to pay an upfront fee of $5 \%$ of your claim. To claim $£ 200,000$, you will need to find $£ 10,000$. That is a $576 \%$ increase on the current fee of $£ 1,515$.' Also see the Table of percentage increases set out at Civil Justice Council, Response to Ministry of Justice Statutory Consultation Letter Court Fees: Enhanced Charging, 2014, at 2.

25. Ministry of Justice, Enhanced Court Fees - The Government Response to Part 2 of the Consultation on Reform of Court Fees and Further Proposals for Consultation (2015), at 8.

26. See Judiciary of England and Wales, above n. 14, at 4 ff., 'This marks a fundamental change in policy. Until now the Government has accepted that fee remissions, provided in the public interest for those unable to pay court fees, should be borne by society at large.'

27. The Civil Proceedings Fees (Amendment) Order 2014 (SI 2014/874); Civil Proceedings and Family Proceedings Fees (Amendment) Order 2015 (SI 2015/576)

28. Ministry of Justice, Courts and Tribunal Fees - The Government's response to consultation on enhanced fees for divorce proceedings, possession claims, and general applications in civil proceedings and Consultation on further fee increases (2015).

29. Comment reported generally in the Law Gazette and New Law Journal and in the consultation responses to the Ministry of Justice's various consultations, by way of example, see above n. 14; Litigation Trends Survey 2015 - Fees a Crowd, New Law Journal (January 2015); Small Businesses Chasing Late Payment will be Hit by Court Fee Rise, Bar Council, 19 January 2015, available at: <http://www.barcouncil.org.uk/ media-centre/news-and-press-releases/2015/january/small-businesseschasing-late-payment-will-be-hit-by-court-fee-rise>/ (last accessed, 15 November 2015); J. Hyde, Court Fee Hike Set for Next Week, Law Gazette (2 March 2015). real, adverse impact on access to justice, or on the aim of increasing fee income. It did so on the basis of a research study it commissioned to accompany its reform proposals (the 2013 research report). This study, which rested on an evidence base of eighteen telephone interviews, formed the basis of the Ministry's conclusion that court fee levels were not a significant factor in individuals' decision-making process when they considered whether to commence proceedings. ${ }^{30}$

There are, however, problems with the 2013 research study and its evidence base. First, it is difficult to see how such a small number of interviews could be seen to be properly robust; that such a small survey could provide a valid foundation for sound conclusions. It is instructive here to consider that the Ministry of Justice, in a previous examination of the effect of court fee increases in 2007 (the 2007 research study), used a sample of 544 court users and concluded on the strength of that even small increases in court fees would adversely affect claiming rates: the greater the increase the greater the adverse effect. ${ }^{31}$

Secondly, and a consequence of the limited number of interviewees, it cannot be said that the study is properly representative of court users. Of the eighteen interviewees, six were large debt recovery organisations with their own in-house legal teams, two were debt recovery agencies with their own in-house legal teams, four were solicitors who specialised in debt recovery, two were personal injury solicitors, and four were private client family law solicitors. ${ }^{32}$ The study therefore failed to consider the potential impact on individual litigants, small and medium businesses, or solicitors in these areas, even if it could be said - which it cannot - that it properly considered the areas of debt recovery, personal injury, and family law work. Equally, it failed to consider entirely the effect of court fee increases on any litigants or solicitors outside these areas, i.e., in immigration, social security, employment, contractual, negligence, clinical negligence, landlord and tenant, judicial review etc., disputes.

Given these two methodological flaws it is difficult to see what, if any, weight could be given to the 2013 research study's conclusions, not least because the pauc-

30. Ministry of Justice (Cm8751, 2013) at 28 and its accompanying research paper, Ministry of Justice, Potential Impact of Changes to Court Fees on Volumes of Cases Brought to the Civil and Family Courts (Ministry of Justice Analytical Services Insight Paper, 2013), at 1; and see, I. Pereira, P. Harvey, W. Dawes \& H. Greevy, The Role of Court Fees in Affecting Users' Decisions to Bring Cases to the Civil and FamiIy Courts: A Qualitative Study of Claimants and Applicants (Ministry of Justice Analytical Series 2014), at 43-44, which on an evidence base of 31 interviews of litigants who had brought claims concluded that fee increases would, in general, not deter individuals bringing claims. While its evidence base was greater than that of the study upon which the fee increases were predicated, it is still not of such a level as to be robust numerically or, given its focus on individuals who had chosen to bring claims, qualitatively robust. Neither the 2013 nor 2014 studies begin to approach the 2007 study in quantitative or qualitative terms.

31. Ministry of Justice Research Unit, What's Cost Got to Do with It? - The Impact of Changing Court Fees on Users (Ministry of Justice Research Series 4/070, 2007), at 7.

32. Ibid., at $55 \mathrm{ff}$ 
ity of that study's evidence base cannot but be highlighted by the strength of the 2007 study's evidence base. Given the comparison that can be drawn between the two studies, rather than placing any weight on the 2013 study's conclusions, the better conclusion is that to be drawn from the 2007 study, i.e., contrary to the view taken by the government that the 2013 fee increases will have no adverse effect, its early research demonstrates that there will be adverse consequences on claiming rates, such that the higher the fee increase the fewer claims will be issued.

Secondly, comparative evidence from the Employment Tribunal suggests that the potential adverse impact may be severe. Historically, claimants were not required to pay issue fees to bring Employment Tribunal claims. In 2013 issue fees were introduced in order to deter vexatious claimants and help reduce government expenditure. ${ }^{33}$ The new fees, described as relatively modest ${ }^{34}$ by the government, produced a significant reduction in claims being issued. As noted by Pyper and McGuinness,

The introduction of fees coincided with a steep decline in the number of cases received. Employment tribunals received 32,671 fewer single claim cases during October 2013-September 2014 compared to the previous year, a $64 \%$ decrease. The number of multiple claim cases was down 3,527, a $67 \%$ decrease. $^{35}$

162 The government has accepted that the result was causal not coincidental. ${ }^{36}$ The reforms thus produced a significant decrease in claims notwithstanding the fact that the fees were set at a low level. Figures are not available to show the percentage of claims prior to the fee introduction that could properly be defined as vexatious. ${ }^{37}$ It is not therefore clear what proportion of the decrease in claims can properly be viewed as non-vexatious, i.e., genuine claims. On the assumption, however, that only a small number of claims are properly vexatious, it is not difficult to draw the conclusion that the percentage decrease in claims has produced a real decline in genuine claims being litigated. This is not an unreasonable assumption as only $13 \%$ of claims were, historically,

33. The Employment Tribunals and the Employment Appeal Tribunal Fees Order 2013 (SI 2013/1893), for a discussion see, D. Pyper and F. McGuinness, Employment Tribunal Fees (House of Commons Briefing Paper, Number 07081, 12 January 2015); also see Tribunal Statistics Quarterly April-June 2014, Ministry of Justice Statistics Bulletin; Tribunals and Gender Recognition Certificate Statistics Quarterly July-September 2014, Ministry of Justice Statistics Bulletin; Tribunals and Gender Recognition Certificate Statistics Quarterly October-December 2014, Ministry of Justice Statistics Bulletin and M. Downer et al., Evaluation of Acas Early Conciliation Scheme (Research Paper 04/15, 2015), at 10 .

34. Cited by Lord Beecham, debate on Civil Proceedings and Family Proceedings Fees (Amendment) Order 2015 (4 March 2015: Column 312).

35. Pyper and McGuinness, above n. 33, at 3.

36. Beecham, above n. 34.

37. E. Ground and M. Stein, Dealing with Vexatious Employment Tribunal Litigants, Nabarro LLP, 2013, available at: <http://www.nabarro.com/ Downloads/Vexatious_tribunal_litigants.pdf > (last accessed, 15 November 2015). struck out on jurisdictional grounds that would have encompassed vexatious claims. As such it can, it seems, properly be said that the reform has produced a reduction in access to justice.

Given the paucity and criticisms that can be raised in respect of the evidence base on which the court fee increase was predicated and the consequences of modest fees being introduced into the Employment Tribunals, it is not unreasonable to conclude that there is a real risk that the civil court fee increases and any introduction of enhanced fees will produce a similar result to that which occurred in the Employment Tribunals, if not a more adverse one. The practical consequence of this set of austerity-induced reforms might thus be to produce a serious reduction in and denial of access to civil justice. At the very least, it is difficult to see the basis for the assumption that the fee increases will have no such adverse impact, as noted by Lord Beecham. ${ }^{38}$ On the contrary there appears to be a real risk, as the Civil Justice Council put it, that these reforms will undermine the principle of equality before the law as the differential nature of the fee increases can be understood to disproportionately affect litigants of modest means and small and medium enterprises. ${ }^{39}$

While the actual effects on the number of claims being issued and on access to justice remain unclear at June 2015, two more concrete conclusions can be drawn from civil court fee reform. First, if the fee increase produces a reduction in claims being issued, the reforms are likely to be self-defeating. The increases were predicated on reducing the taxpayer subsidy for the civil justice system. ${ }^{40}$ If claim numbers reduce in the light of fee increases, the benefits to the taxpayer will either, in whole or in part, not be realised. This will either result in the Ministry of Justice having to seek further savings from the civil justice system to meet its savings targets, increase fees further thereby compounding the problem, or continue to subsidise the system. Each potential alternative would undoubtedly entail further reform of the system. Given the overall commitment to lowering public sector spending, the likely choice taken would be one that saw no further increase in public spending on the civil courts, which would result in a furthering winnowing of the system with an attendant decrease in the system's ability to deliver civil justice effectively. Secondly, the increases, and the fact that they are predicated on eliminating both taxpayer subsidy for the system and to enable the government to reduce and then eliminate its residual role in funding fee remissions, further embed the flawed conception of the justice system that has been in place since the 1980s. It would further entrench the idea that the civil justice system ought to be funded by its users because, rather than provide a public good, it simply provides a consumer service which, like any other such service, should be paid for by the user. It may therefore mark a further step along a

38. Beecham, above n. 34 .

39. Civil Justice Council, above n. 24, at 2.

40. And consequently the family justice system. 
road towards the separation of the State from the English civil justice system. ${ }^{41}$

\subsection{Civil Legal Aid Reforms - Questioning Fundamental Aspects of the Civil Justice System}

\subsubsection{Civil Legal Aid Reforms}

The availability of civil legal aid has been a central feature of the English civil justice system since it was introduced by the Legal Aid and Advice Act 1949. Originally, approximately $80 \%$ of the population were eligible for such an aid in a limited number of categories of claim. Over the next 50 years, its scope initially grew to cover more categories of claim while eligibility declined per head of population. By the late 1990 s, $52 \%$ of the population were eligible for civil legal aid. This had declined to $41 \%$ by 2001 following the removal of most personal injury claims from legal aid cover in $1999 .{ }^{42} \mathrm{By}$ 2007 it stood at $29 \%{ }^{43}$ In 2010 further reform of the system was considered. ${ }^{44}$

The 2010 reform proposals were predicated on two grounds. First, it was necessary to reduce legal aid spending because the State continued to spend too much money on it. As the Lord Chancellor put it, notwithstanding serial reductions in legal aid cover, England and Wales continued to have 'one of the most expensive (legal aid systems) in the world, available for a very wide range of issues, including some which should not require any legal expertise to resolve'. ${ }^{45}$ Expenditure consequently had to be brought under control so as to ensure that it was only provided for serious, meritorious cases, for classes of case for which the public interest required funding to be made available. A too generous system needed to be brought under control. Secondly, and in furtherance of the government's overall plan to reduce public expenditure, reform was necessary. ${ }^{46}$ As the Lord Chancellor explained, 'Legal aid must also play its part in fulfilling the Government's commitment to reducing the fiscal deficit and returning this country's economy to stability and growth. ${ }^{47}$

While the government acknowledged that, in its view, the legal aid system was in need of fundamental reform notwithstanding the financial crisis, the need for reform was acute given the financial crisis. The necessity for reform arose against 'a backdrop of considerable finan-

41. See further, J. Sorabji, Justice in a Market State - An English Prolegomenon, in Citizen-State-International Community: A Collection of Studies (C.H. Beck) (2014); Genn, above n. 13; T. Farrow, Civil Justice, Privatization and Democracy (Toronto) (2014).

42. See Access to Justice Act 1999.

43. See S. Hynes and J. Robins, The Justice Gap (2009) (LAG), at 71 for an overview of the history of the development of legal aid.

44. Ministry of Justice, Proposals for the Reform of Legal Aid in England and Wales (CP7967/2010); further reductions, primarily aimed at reducing criminal legal aid albeit with some reductions to civil legal aid, were proposed in 2013, see Ministry of Justice, Transforming Legal Aid: Delivering a More Credible and Efficient System (CP14/2013).

45. Ministry of Justice (CP7967/2010), at 3.

46. As noted, ibid., at 15 .

47. Ibid. and see Ministry of Justice, Reform of Legal Aid in England and Wales: The Government Response (CM8072/2011), at 3. cial pressure'. The specific reform proposals were specifically 'developed with the aim of providing a substantial contribution to the Ministry of Justice's target of a real reduction of $23 \%$ in its budget, worth nearly $f_{2}$ bn in 2014-15'. The proposals were to reduce public spending by $£ 350$ million, which was $17.5 \%$ of the required overall reduction. This reduction in 'public spending [was] essential to economic recovery'. ${ }^{48}$ The reduction in civil legal aid spending would have thus gone ahead irrespective of it being, arguably, higher than in other jurisdictions.

Austerity was thus both the efficient and final cause of the reforms, ${ }^{49}$ a conclusion underpinned by the Justice Minister's acknowledgment in Parliament, following their introduction, that the reforms were implemented on an inadequate evidence-base because 'the economic situation that the Government inherited did not allow that luxury'. ${ }^{50}$ If austerity had not been the main driver of reform, time could have been spent on both securing robust comparative evidence as to civil legal aid spending in the context of differing approaches to the structure of civil justice systems and into its potential effects. That austerity was the main driver justified the actual approach taken and the lack of evidence gathering.

The civil legal aid reforms, following on from the 2010 consultation, were effected in 2012 by the Legal Aid, Sentencing and Punishment of Offenders Act 2012. It came into force in April 2013 and reduced civil legal aid by $40 \%$, such that it stood at $£ 157$ million for a population of 53.5 million or approximately $£ 3$ per head per annum. ${ }^{51}$ Consequently, very few types of civil claim fall within the scope of legal aid. Areas still within scope, albeit subject to stringent limits, are actions against the police; clinical negligence; community care; debt; education; employment; housing; immigration and asylum inquests; mental health; personal injury, in very

48. Ministry of Justice, above n. 44 , at 5 and 15

49. See, for instance, Ministry of Justice, Transforming Legal Aid: Next Steps (September 2013), at 3, 'This Government has embarked upon a process of repairing the public finances after years of reckless borrowing and financial crisis under the previous administration. The Ministry of Justice will see its budget reduce by nearly a third between 2010 and 2016. No area of our spending has been immune from scrutiny in these circumstances. Our legal aid system is a major part of my Department's budget, and it is therefore appropriate that we look to make savings here too.' And see Ministry of Justice, Transforming Legal Aid - Next Steps: Government Response (February 2014), at 6, in which the Ministry of Justice noted that the civil legal aid reforms arising from the 2010 consultation did not realise sufficient savings and thus further reductions, primarily in criminal legal aid expenditure, were necessary.

50. S. Vara M.P. cited in House of Common's Justice Committee, Impact of Changes to Civil Legal Aid under Part 1 of the Legal Aid, Sentencing and Punishment of Offenders Act 2012 (HC 311, 2015), at 8.

51. For critical comment see, Low Commission, Tackling the Advice Deficit - A strategy for Access to Advice and Legal Support on Social Welfare Law in England and Wales (LAG, 2014), Annex 11 at 1. 
limited circumstances such as claims involving infants; public law and judicial review; and welfare benefits. ${ }^{52}$

It was anticipated prior to their introduction that these reforms would be highly detrimental to effective access to justice, that they would, as the Civil Justice Council concluded, 'have a disproportionately adverse effect on the most vulnerable in our society' ${ }^{53}$ and that they would lead to significant increases in individuals having to litigate without legal advice or representation (litigants-in-person or LiPs). ${ }^{54}$ The Civil Justice Council's conclusions were based on 'informed prediction(s)', such as those provided by free legal advice and support agencies based on their experience of increases of individuals seeking their services following previous reductions in legal aid provision. ${ }^{55}$ Evidence regarding the actual effects of the reforms is, however, thin, primarily because no data is kept concerning either the rate at which individuals litigate or the number of LiPs appearing before the civil courts. ${ }^{56} \mathrm{~A}$ limited amount of evidence suggests that the predictions have been borne out. Data shows that, since 2013, there has been a $62 \%$ drop in civil cases that have been granted legal aid funding, ${ }^{57}$ that in the year 2013-2014, '326,004 fewer cases than would have been expected without the (2012 Act) reforms' received civil legal help, i.e., advice funding and ' 36,537 fewer cases' ${ }^{\prime 58}$ received civil legal representation funding. The free advice agencies, those that provided the Civil Justice Council with informed predictions', have seen significant increases in vulnerable indi-

52. See Legal Aid, Sentencing and Punishment of Offenders Act 2012, schedule 1. For a discussion of the areas that remain in scope, see $\mathrm{V}$. Ling and S. Pugh, Legal Aid Handbook 2013-2014 (LAG, 2013), at 25 ff.; Bar Council, Changes to Legal Aid - A Practical Guide, available at: <http://www.barcouncil.org.uk/media/201552/changes_to_civil_legal_ aid_practical_guidance_for_the_bar.pdf> (last accessed, 15 November 2015); G. Cookson, Unintended Consequences: The Cost of the Government's Legal Aid Reforms (2011), available at: <https://www.kcl.ac. uk/campuslife/student/news/stories/UnintendedConsequencesFinalReport.pdf> (last accessed, 15 November 2015), at 13.

53. Civil Justice Council, Access to Justice for Litigants in Person (or SelfRepresented Litigants) (2011), at 8

54. Ibid., at 6-9; R. Lowe, Lord Woolf UK Legal Aid Cuts May Cause 'extreme' Psychological Damage, IBA News, 20 March 2013, available at: <http://www.ibanet.org/Article/Detail.aspx?ArticleUid=fc020f7eea11-4895-8495-88d876d41c63> (last accessed, 15 November 2015).

55. Ibid., at 8 and 17.

56. As R. Trinder et al., Litigants in Person in Private Family Law Cases (Ministry of Justice Analytical Series, 2014), at 2, concluded in 2014 it remained to be seen whether the reforms would 'lead to a sustained' increase the numbers of LiPs. Evidence by the Chief Executive of Her Majesty's Courts and Tribunals Service, Natalie Ceeney to a Parliament implied that it has up-to-date records, although they are not apparently in the public domain, see House of Commons, Justice Committee, evidence session, 13 October 2015.

57. Ministry of Justice Legal Aid Figures, June 2014, available at: <http:// static.guim.co.uk/sys-images/Guardian/Pix/pictures/2014/9/3/ 1409762794943/Legalaidgraphic.jpg?guni=Article:in\%20body \%20link> (last accessed, 15 November 2015); A. Zuckerman, No Justice Without Lawyers-The Myth of an Inquisitorial Solution, 33 Civil Justice Quarterly 355, at 355 (2014). 'According to Government figures, 623,000 of the 1 million people who benefited from Legal Aid annually will be denied access to this aid from April 1, 2013, when the Legal Aid, Sentencing and Punishment of Offenders Act 2012 became effective.'

58. National Audit Office, Implementing Reforms to Civil Legal Aid (HC 784, 2014), at 2. viduals calling on their services for debt advice, employment, housing, social security and immigration, and asylum advice and support. The Personal Support Unit, for instance, reported that it provided free advice and assistance to nearly 40,000 individuals in 2014-2015 and in 2015-2016 expects to assist approximately 50,000 individuals seeking such a help. In 2012-2013, the year before the legal aid reforms were introduced it provided such assistance to approximately 12-13,000 individuals. ${ }^{59}$ Other evidence shows a variety of adverse consequences of the reforms ranging from a reduction in numbers seeking such legal support that remains available both in terms of individuals seeking legal aid where it does remain available, due to a failure to appreciate its true extent, and significant reductions in a variety of free legal advice services which have themselves lost funding. ${ }^{60}$ Unsurprisingly in the circumstances, the House of Commons' Justice Committee concluded the reforms harmed access to justice. ${ }^{61}$

The most significant noticeable impact on the civil courts arising from the legal aid reforms has, however, concerned LiPs. The expectation that the reforms would lead to a significant increase in LiPs appears to have been borne out. As the Justice Committee concluded in the light of a wide range of evidence presented to it,

...there has been a significant rise in the number of self-represented litigants (LiPs) before the courts but even approximate numbers are difficult to determine. Figures for litigants in person are not collated in the civil courts, but the Master of the Rolls, Lord Dyson, told us that the civil courts had experienced a significant impact from a rise in litigants in person. ${ }^{62}$

59. The Personal Support Unit, Annual Report 2014-2015 (2015), at 3.

60. See, for instance, the Low Commission Report and House of Common's Justice Committee (HC 311, 2015).

61. House of Common's Justice Committee (HC 311, 2015), at 3.

62. House of Common's Justice Committee (HC 311, 2015) at 36, noting evidence from Lord Dyson MR, head of civil justice, and drawing on comparative evidence from the family justice system, which showed 'strongly suggests not only a significant increase in parties without legal representation but also that litigants in person may be appearing in more complicated cases or be less able to represent themselves' and Judicial Executive Board, Written Evidence - Justice Committee Inquiry: Impact of Changes to Civil Legal aid under the LEGAL AID, Sentencing and Punishment of Offenders Act 2012 (2014); Civil Justice Council, Civil Justice Council Response to Justice Committee Inquiry: Impact of Changes to Civil Legal aid under the Legal Aid, Sentencing \& Punishment of Offenders (LASPO)Act 2012 (2014), 'The escalating cost of using lawyers in civil litigation in circumstances where legal aid has never been available has coincided with the major legal aid reforms under the Legal Aid, Sentencing and Punishment of Offenders Act 2012 (LASPO) which took effect in April 2013. This has resulted in a very significant rise in the proportion of litigants in person.' And see, $Q$ v. $Q$ [2014] EWFC 31 at [11]; Bar Council, The Legal Aid, Sentencing and Punishment of Offenders Act 2012 (LASPO): One Year On - Final Report (2014), at 29. 
The Lord Chief Justice's Annual Report 2014 reiterated the point, ${ }^{63}$ as did a survey conducted by Cookson on behalf of the Bar Council. ${ }^{64}$ This increase in LiPs has led to a number of fundamental aspects of the English approach to civil justice being questioned, alternative approaches being proposed and, in some cases, being introduced. It is this that is producing what is likely to be the most far-reaching consequence of austerity on the civil justice system. ${ }^{65}$ The following section considers those issues and approaches.

\subsubsection{Questioning the Fundamentals}

The increase in LiPs has produced two significant areas of reform: the first concerns the English civil justice system's commitment to adversarial process; the second has seen a rise in the use of non-legally qualified individuals as advocates contrary to the traditional approach that strictly regulates such rights.

\subsubsection{Inquisitoriality}

The English civil justice system is primarily adversarial. ${ }^{66}$ It has traditionally been characterised by a passive judiciary who ensured that procedural rules were observed and determined claims based on the law and on evidence submitted by the parties. Responsibility for case progression to trial, gathering, submitting, and testing evidence was that of the parties. The Woolf reforms of the late 1990 s effected a significant change to one aspect of this traditional approach through the introduction of active court-based case management. Since 1999, the court, rather than the parties, has been responsible for ensuring cases progress to trial economically and efficiently. ${ }^{67}$ Parties are under a duty to assist the court carry out this duty. ${ }^{68}$ This reform, however, left the fundamental structure of the adversarial process untouched. It did not, for instance, provide judges with any power to gather evidence. Nor did it permit judges to test witness evidence ${ }^{69}$ or require of the court's own motion the production of documentary evidence that the parties had for whatever reason not adduced at trial. ${ }^{70}$ While it removed one aspect of the adversarial system - party autonomy over case progression - it left the remainder untouched. Case management powers did

63. The Lord Chief Justice's Annual Report (2014), at 12, 'The escalating cost of using lawyers in civil litigation in circumstances where legal aid has never been available has coincided with the major legal aid reforms under the Legal Aid, Sentencing and Punishment of Offenders Act 2012 (LASPO) which took effect in April 2013. This has resulted in a very significant rise in the proportion of litigants in person.'

64. Bar Council, above n. 62, at 67.

65. An overview of the issues can be found in UCL Judicial Institute, Litigants in Person: What Can Courts Do? - Background Papers (2014).

66. Although see, A. Kessler, Our Inquisitorial Inheritance, 90 Cornell Law Review 1181 (2004-2005).

67. CPR rr.1 and 3.

68. CPR r.1.3.

69. Jones v. National Coal Board [1957] 2 Q.B. 55 at 64; Southwark London Borough Council v. Kofi-Adu [2006] EWCA Civ 281; [2006] H.L.R. 33, at [148].

70. Air Canada v. Secretary of State for Trade [1983] 2 A.C. 394, at 439 'There is no independent power in the court to say that, nevertheless, it would like to inspect the documents, with a view to possible production, for its own assistance.' not thus equate to, or provide, investigative or inquisitorial powers; a point highlighted by Lord Dyson JSC in Al Rami v. The Security Service in 2012. Discussing the extent of the court's power to regulate its own process, he noted that it was, 'surely not in doubt that a court cannot conduct a trial inquisitorially rather than by means of an adversarial process (at any rate, not without the consent of the parties)' ${ }^{71}$

The increase in LiPs as a consequence of austerity has called into question the commitment to adversarial process: it has raised the very doubt Lord Dyson JSC thought to be beyond question. It has done so because, as Lord Thomas CJ put it in evidence to Parliament, the adversarial system cannot work without legal aid, i.e., without the provision of funding for legal representatives. ${ }^{72}$ Party autonomy, and its converse judicial passivity, in framing and controlling the substantive content of the litigation, in investigating the issues, securing and testing relevant evidence, as well as ensuring effective navigation of relevant procedural rules and compliance with procedural obligations is predicated on the presence of lawyers. ${ }^{73}$ In the absence of lawyers, the court is faced with a dilemma: either take on the lawyers' role in addition to its adjudicatory role or, potentially, fail to discharge its duty as a court of law to provide a fair trial. As Ryder LJ explained it, in the context of family proceedings in $C$ (a child), following a failure by two LiPs to secure and submit appropriate evidence and information in advance of a hearing so that central issues in the claim were neither identified nor answered at the hearing,

Appointments of the type I have so far been describing take time, particularly where one or more of the parties are litigants in person as a consequence of the provisions of LASPO 2012. If the dispute is not immediately susceptible of conciliation or out of court mediation it will require a lawyer's analysis. This is after all a court of law. In the absence of lawyers, the judge has to do that and to do that without assistance and sometimes with quite vocal hindrance. That requires more time than in a circumstance where the lawyers can be required to apply the rules and practice directions, produce the witness statements, summaries, analyses and schedules, obtain instructions and protect their lay client's interests. Where a court is faced with litigants in person the judge has to do all that while maintaining both the reality and perception of fairness and due process. ${ }^{74}$

Similar problems have been identified in civil claims. Tugendhat $\mathrm{J}$ in Mole v. Hunter, for instance, explained that in the absence of legal representatives the court had

71. [2012] 1 A.C. 531 at 22

72. Lord Thomas CJ, Unrevised Transcript of Evidence Taken before the Select Committee on the Constitution (House of Lords, 7 May 2014), at 15.

73. See, for instance, Tinkler v. Elliott [2012] EWCA Civ 1289, in which a failure to appreciate the process for challenging a decision led to a claimant being unable to do so effectively.

74. [2013] EWCA Civ 1412 at [40]. 
to adopt an essentially investigative approach. ${ }^{75} \mathrm{He}$ did so by consent of the parties, albeit this was in his view unnecessary, as the court's case management powers provided the jurisdiction for such an approach to be taken (see CPR r.3.1(2)(m)). ${ }^{76}$ His approach also required the court to question the parties to ascertain the nature of the dispute, to place the parties' case papers in an appropriate order, to carry out preparatory work that would otherwise be carried out by lawyers, particularly by junior lawyers. It had to do so 'in order for the case is to be tried justly'.77

Necessity, in the absence of lawyers, has therefore meant that courts have had no choice but to carry out administrative functions ordinarily the province by lawyers. More significantly however, as the two cases cited demonstrate, they have had to start to move away from the traditional, adversarial, idea that the judge should play no part in evidence-gathering, issue identification, or in examining parties or witnesses at trial. While such a move to a substantively quasi-inquisitorial (in the sense that a fully inquisitorial process would be one that enabled the court to initiate proceedings) was initially mooted as an idea that needed consideration by, for instance, a Judicial Working Party on LiPs in $2013^{78}$ and then by the Lord Chief Justice in $2014,{ }^{79}$ the pace of change has been faster than might have been expected for such a significant shift in approach. Reform has been implemented in two distinct ways.

The first change, which partially outran the calls for considered reform, encompasses the change in practice in the courts already outlined. It goes wider than this though. The judiciary has not simply started to develop more inquisitorial practices; it has taken an active role in reforming the justice system by developing a number of measures to assist LiPs. It has been instrumental in the establishment of pro bono legal advice and assistance schemes in the High Court. Such schemes are operated by the legal profession and seek to facilitate the provision of such assistance and, in some cases representation in court, by junior or trainee lawyers. ${ }^{80}$ The judiciary has also devised a number of legal practice guides, aimed at giving LiPs straightforward guidance on court

75. [2014] EWHC 658 (QB) at [107]-[119]; also see, for instance, Re $R$ (a child) [2014] EWCA Civ 597 at [3].

76. It provides that the court may 'take any other step or make any other order for the purpose of managing the case and furthering the overriding objective'.

77. Ibid., at [111]. As he noted, the use of an expensive resource - the judicial - to carry out a role normally played by junior lawyers was a false economy both in terms of time and money. At the present time it does not appear that this transfer of work from the legal profession to the courts would cause a significant drag on court resources does not appear to have been borne out, see Ministry of Justice, Government Response to Justice Committee's Eighth Report of Session 2014-15 (2015), at 3.

78. Report of the Judicial Working Group on Litigants in Person (Judicial Office) (2013), which was established to consider how to adapt the civil justice system to enable it to manage claims effectively for LiPs

79. J. Thomas, Reshaping Justice (Justice Lecture) (3 March 2014), at [29][32].

80. E.g., The Chancery Bar Litigant-in-Person Scheme. and trial procedure. ${ }^{81}$ There has also been an increased emphasis on revising court forms to render them more comprehensible to individuals who have had no legal training.

The second change concerns the rules of court. In its report from 2013, the Judicial Working Party on LiPs identified three modifications to the CPR that could be made. It recommended, where one or more parties to claim was a LiP, that: (i) a dedicated rule be introduced that made 'specific modifications to other (procedural) rules'; (ii) a new case management power to provide for an inquisitorial process be introduced; and/or (iii) a new provision that provided for a fully inquisitorial process be introduced. ${ }^{83}$ While it has been acknowledged, as previously noted by Tugendhat $\mathrm{J}$ in Mole v. Hunter, that CPR r.3.1(2)(m) provides sufficient power to achieve what the recommendations sought to effect, they have been acted on. From October 2015, in order to emphasise the requirement that the courts adapt and use the wide powers that the rules of court already provide to them, a discrete rule (CPR r.3.1A) is to be introduced into the CPR. ${ }^{84}$ This will implement the first and second of the three recommendations and will, amongst other things, require the court to 'adopt such procedure at the hearing as it considers appropriate to further the overriding objective', to adapt case management directions as necessary, and, as an exception to the general approach to evidence provided by CPR rr.32 and 33, to ascertain the nature of relevant witness evidence and where necessary question witnesses. The idea that the court can generally adapt its process to be inquisitorial or investigative is thus to become a formal aspect of its powers. The idea, expressed by Lord Dyson JSC, that the civil process cannot be carried out inquisitorially is no longer one that holds true.

In addition to these reforms fustice, a law reform body, has recently proposed an even greater embrace of inquisitorial techniques. In its research paper, Delivering Fustice in an Age of Austerity, ${ }^{85}$ it set out a detailed proposal for fundamental reform of the civil justice system. Its proposal is an updated version of Professor Sander's multi-door courthouse model developed in the 1970s. ${ }^{86}$ Its recommendations are explicitly made on the basis that the justice system has been placed under acute pressure through a combination of legal aid cuts and a sharp reduction in public spending on the courts. It understands these austerity measures to have made it

81. See, for instance, Civil Justice Council, A Guide to Bringing and Defending a Small Claim (2013); Judicial Office, The Interim Applications Court of the Queen's Bench Division of the High Court - A Guide for Litigants in Person (2013); H.H.J. Bailey et al., A Handbook for Litigants in Person (2013).

82. See J. Sorabji, Promptly Setting Aside a Judgment Given in a Party's Absence: Tinkler v. Elliot, 32 Civil Justice Quarterly 9 at 13 (2013).

83. Report of the Judicial Working Group on Litigants in Person Report at 24.

84. Civil Justice Council, Helping Litigants in Person Prepare for Court (July 2015).

85. Justice, Delivering Justice in an Age of Austerity - A Report (2015).

86. F. Sander, Varieties of Dispute Processing, 70 Federal Rules Decisions, 79, 111 (1976). 
increasingly difficult for litigants, increasingly unrepresented, to 'navigate (the) adversarial justice system' ${ }^{87}$ In order to remedy this access to justice deficit, its primary recommendation is the introduction of a legally qualified court officer (a Registrar) who, while not a judge, would be responsible for managing claims once they were issued. Such officers would be required to clarify the issues in dispute, determine what evidence is required and direct the parties to submit it, review the evidence and, in the light of that review, determine the appropriate means of resolving the dispute, i.e., through striking it out, carrying out an early neutral evaluation, directing it to mediation or transferring it to a judge for adjudication. ${ }^{88}$

It is, at this time, not apparent whether and if so to what extent the Fustice report may be acted upon. Implementation of its proposals will require a significant restructuring of the civil courts and judiciary and will, through the employment and training of sufficient number of Registrars, undoubtedly be an expensive exercise even if only in the short term. Given the potential expense, it is perhaps unlikely that its recommendations will be implemented in full. As elements of the Report cohere with other developments already being introduced, as noted above, it is likely that at least some of its recommendations will be introduced. The role of the Registrar could, for instance, be adapted so that existing procedural judges carry it out with the assistance of such lawyers as the court service already employs. This would consequently increase the level at which the court carried out an active investigation into the issues in dispute, helped the parties to identify and refine them, and played an active role in identifying evidence and requiring its submission to the court. At the very least it provides a basis upon which the judiciary could consider how to further develop the more inquisitorial approaches to the conduct of litigation that they have developed, noted above. Moreover it shows quite clearly that, along with those judicial developments, an idea that was rejected out of hand in the $1950 \mathrm{~s}^{89}$ - that the English civil justice system could adopt a more inquisitorial approach - is now moving into the mainstream both in terms of actual practice and further, future reform.

\subsubsection{McKenzie Friends}

The reduction in civil legal aid has had one further specific consequence. It has resulted in increasing numbers of LiPs obtaining the help of individuals who, although not qualified or regulated lawyers, provide legal assistance. Historically such individuals, colloquially known as McKenzie Friends, have provided moral support and assistance to LiPs as part of every litigant's common law right to receive reasonable assistance in the prosecution

87. Justice, above 85 , at 1 .

88. Ibid., at 20-25

89. The Committee on Committee on Supreme Court Practice and Procedure, Final Report (Cmd 8878, 1953) at [25]-[26]. of litigation. ${ }^{90}$ Over the last 20 years, and most acutely since the 2012 legal aid reforms came into effect, increasing numbers of individuals have provided such support and, where authorised by the court on a caseby-case basis to do so, acted as advocates for LiPs in court. ${ }^{91}$ Increasingly, such McKenzie Friends, have and are marketing themselves as 'professional' and charging for their services.

While the provision of legal advice is not restricted to lawyers, generally speaking the exercise of rights of audience in courts is regulated and restricted to lawyers. ${ }^{92}$ In order to improve access to justice there has been a tendency, since 2013, in both the family and civil courts to take a more lenient approach to the grant of advocacy rights to McKenzie Friends by the courts. Faced with an increase in LiPs who are unfamiliar with court procedure, who may be nervous of addressing the court or may not be in a position to question witnesses or present evidence, the availability of a McKenzie Friend who may, and in some cases will, be able to present the litigant's case more effectively, the courts have begun to take a more liberal approach to the grant of such rights than is strictly permissible. ${ }^{93}$ This approach, allied to increasing demand as lawyers become increasingly unaffordable following the removal of legal aid, has led to increasing numbers of unregulated 'professional' fee-charging McKenzie Friends. It has also led to calls for the courts to take an even more accommodating approach to them and to granting them rights of audience, such that they become an accepted part of the justice system. ${ }^{94}$

Unlike those developments relating to inquisitorial processes, which have been broadly welcomed, ${ }^{95}$ these developments and the prospect of increased use of McKenzie Friends, particularly fee-paid ones, have met with a degree of concern, particularly from the legal profession. ${ }^{96}$ These concerns fall into two categories. First, there are practical concerns stemming from the fact that McKenzie Friends need not have any legal training, that they owe no duty to the court and may not properly understand or apply applicable duties of confidentiality or come within the protection afforded by way of legal professional privilege. Furthermore concerns arise because they are not subject to any form of professional regulation, discipline, or requirements to hold professional indemnity insurance. The quality of their assistance may thus be variable, more variable than a

90. R v. Leicester City Justices, ex parte Barrow [1991] 260 at 289; McKenzie v. McKenzie [1970] 3 W.L.R. 472

91. For a discussion, see Report of the Judicial Working Group on Litigants in Person (2013), at $26 \mathrm{ff}$

92. Legal Services Act 2007.

93. The test for the grant of such rights is summarised in: Practice Guidance (McKenzie Friends: Civil and Family Courts) [2010] 1 W.L.R. 1881

94. Legal Services Consumer Panel, Report: Fee-Charging McKenzie Friends (2014).

95. Although for criticism of this development, see Zuckerman, above $\mathrm{n}$. 57 , at 355.

96. See, for instance, C. Smith, McKenzie Friends Rebuff from Bar, Law Gazette (20 July 2015) noting the Bar Council's concerns. 
lawyer, without the protection afforded to individuals who instruct lawyers.

Secondly, there is a more principled objection to any increased use or legitimatisation of McKenzie Friends. Increasing legitimisation is implicitly predicated on an acceptance of the fact that should an individual not be able to afford a lawyer anybody else, irrespective of their ability or training, will do. If made in respect of medical provision, it is an idea that would be rejected out of hand. If it were suggested, for instance, that the National Health Service was to ration availability of free-atthe-point-of-delivery operations but that those who were to pay for their operations but could not afford to do so could use McKenzie Friends to operate on them, the idea would be viewed as completely unacceptable. It would consign the impecunious to a second-class status, and one that saw them resorting to the untrained and unregulated to perform surgery.

The suggestion that those who cannot afford lawyers should be permitted to resort to untrained individuals because that is the best on offer is a counsel of despair. It is one that cannot properly have any place in a society that claims to provide substantive rather than merely formal equality before the law and equal access to justice. It is, perhaps, the most significant adverse consequence of austerity-induced cuts to civil legal. It is one that the growth of an inquisitorial approach by the courts and the promotion of pro bono legal advice and assistance, as promoted by the courts and the legal profession, may however counteract. If they, or other measures such as the promotion of replacements for civil legal aid such as the development of legal expenses insurance as has occurred in Canada, ${ }^{97}$ do not prevail there is a real risk that the growth of fee-paid McKenzie Friends of varying quality and ability will pose a significant problem for the proper administration of justice for individuals who can ill-afford poor representation and may embed substantive inequality before the law into the justice system. It will make the provision of secondclass justice an accepted part of the civil justice system.

\section{Small Claims and Small Claims Mediation}

Having reviewed a number of developments to the English civil justice system that have arisen as a consequence of austerity, this article now turns to consider an area where austerity might have produced reform: the English small claims procedure and small claims mediation. These are two areas that have undergone recent reforms, ones that coincided with austerity. This section is divided into two parts. The first provides an outline of the two processes. The second considers what effect austerity may have had on their development and con-

97. Canadian Bar Association, Reaching Equal Justice: An Invitation to Envision and Act (Report of the CBA Access to Justice Committee, 2013), at $101 \mathrm{ff}$. cludes that ultimately any reform to the processes could not have met the problems arising from the changes effected to court fees and civil legal aid.

\subsection{The Small Claims Track and Small Claims Mediation}

\subsubsection{Small Claims}

The small claims procedure, sometimes incorrectly referred to as the small claims court, originated in 1973 as an extension of the County Courts' ${ }^{98}$ power to direct a small claim to arbitration. ${ }^{99}$ It was originally intended to provide, 'an accessible, quick, cheap and informal means of deciding disputed civil claims which involve(d) comparatively small sums of money' ${ }^{100}$ The process was reformed as part of the Woolf reforms ${ }^{101}$ and formalised in CPR Pt 27 as one of English civil procedure's three procedural case tracks. ${ }^{102}$ It is designed to provide a speedy, low cost, proportionate process for managing and determining claims of low value. The vast majority of civil claims are small claims, ${ }^{103}$ with, for instance, over $80 \%$ of all personal injury claims being allocated to it. ${ }^{104}$ It is a highly successful aspect of the civil process, benefiting from a high degree of user-satisfaction. ${ }^{105}$

The small claims procedure has a number of features that distinguish it from English civil procedure generally. It applies to all claims whose value is below $£ 10,000$ and to those personal injury claims and housing claims whose value is below $f 1,000 .{ }^{106}$ Other claims may be allocated to it consistently with the CPR's overriding objective of dealing with cases justly and at proportionate costs. Given that it is designed for the use of litigants without resort to lawyers it has two defining features.

98. NB: until 2013 each of the approximately 216 County Courts throughout England and Wales was a separate, distinct, court. In 2013, as a consequence of the Legal Aid, Sentencing and Punishment of Offenders Act 2012, the County Courts were merged into a single, England and Wales-wide, County Court.

99. H. Woolf, Access to Justice: Interim Report to the Lord Chancellor on the Civil Justice System in England and Wales (HMSO) (1995), at 102; and see, N. Andrews, Andrews on Civil Processes (2013), Vol. 1 at 94; County Courts Act 1959, s92 (as amended by the Administration of Justice Act 1977, s17); see further CCR Ord. 19, r.5 in R. Gregory (ed.), The County Court Practice 1983 (1983); CCR ord. 19, rr.1-10 in P. Thompson (ed.), The County Court Practice 1994 (1994).

100. Report of the Review Body on Civil Justice (Cmd 394 of 1988) cited in Woolf, above n. 99, at 104 .

101. Woolf, above n. 99; H. Woolf, Access to Justice: Final Report to the Lord Chancellor on the Civil Justice System in England and Wales (HMSO) (1996).

102. The other two tracks are the fast track (CPR Pt 28), which applies to claims with a value of above $£ 10,000$ and below $£ 25,000$; and the multi-track (CPR Pt 29), which applies to all other claims.

103. See R. Jackson, Review of Civil Litigation Costs: Preliminary Report (2009), Vol. 1 at 47

104. Ibid., at 108

105. L. Bello, Small Claims, Big Claims - Consumers' Perceptions of the Small Claims Process (Consumer Focus, 2010), at 4 and 17. Also see Jackson, above n. 103, at 119; IFF Research, Consumer Experience of the Small Claims Process - Research Report (2010).

106. CPR r.27.1(2) \& r.63.27 
First, unlike civil procedure generally, rights of audience are unrestricted. ${ }^{107}$ Litigants may represent themselves before the court. They may also be represented by anybody of their choosing irrespective of their legal knowledge and experience or lack thereof. Secondly, and necessarily linked to the previous point, the court's traditional commitment to an adversarial process is substantially relaxed. District judges, who conduct the small claims process and trials, can be and generally do take a far more investigative, inquisitorial approach to the conduct of hearings. They do so as they are expressly authorised to 'adopt any method of proceeding at a hearing that [they consider] to be fair...' ${ }^{108}$ Accordingly, and reflecting the fact that litigants or their lay representatives may have little experience of conducting civil proceedings and particularly trials, District judges will, for instance, question witnesses and the parties and direct the provision of such evidence as they conclude is appropriate. ${ }^{109}$

Procedural flexibility is further promoted through the express exclusion from the small claims process of, for instance, the otherwise applicable rules of evidence, rules governing disclosure, and expert evidence. ${ }^{110} \mathrm{Par}$ ties need not give evidence on oath. They need only disclose those documents they intend to rely upon at trial. (The normal rule requires parties to disclose documents adverse to their case or supportive of their opponent's case.) Expert evidence is not generally permitted. ${ }^{111}$ The court can and will often curtail cross-examination; the judge will ordinarily carry out the examination of the parties and witnesses. Trials are informal and generally take place before the District judge in their office rather than in a formal courtroom. ${ }^{112}$ The general expectation is that a trial will last no more than an hour, although some will last for up to 3 hours. Short, reasoned judgements are given and decisions are capable of appeal. Finally, in contrast to English procedure generally, the cost-shifting rule is disapplied. Except in cases where the court determines that one of the parties has conducted the litigation in an unreasonable manner, in which case it can award such costs as it assesses summarily, ${ }^{113}$ the recoverable costs of a small claim and any appeal ${ }^{114}$ are, generally, restricted to any court fees paid by the successful party; fixed legal costs, such as those for issuing the claim; ${ }^{115}$ and any witness expenses, subject to a maximum of $f^{9} 90 .{ }^{116}$ Lawyer's fees are not recoverable.

107. Legal Services Act 2007, Pt 3; The Lay Representatives (Rights of Audience) Order 1999; CPR PD 27 para. 3.1.

108. CPR 27.8, PD 27 para. 4.3.

109. CPR r.27.2(3).

110. CPR r.27.2(1).

111. General guidance is given to litigants in terms of information generally needed in small claims proceedings in CPR PD 27 Appendix A; standard directions are set out at CPR PD 27 Appendix B and C.

112. CPR r.27.8.

113. CPR 27.14(2)(g).

114. CPR r.27.14(2)

115. See CPR r.27.14(2) and CPR r.45.

116. Further fixed costs in specific types of case, i.e., injunctions or certain road traffic accident cases are also recoverable: see CPR r.27.14 and PD 27 para. 7.

\subsubsection{Small Claims Mediation}

The small claims procedure has since the CPR was introduced been a part of the civil process. It culminates, unless the parties abandon their claim or defence or settle their dispute consensually, in a reasoned judgement. Its origins were, however, different. As originally conceived the small claims process was not formally part of the civil process. It was an arbitral process. ${ }^{117}$ While the CPR's introduction formalised small claims arbitration as a small claims process, it also effected an increased emphasis on the use of mediation and other forms of alternative dispute resolution generally. ${ }^{118}$ Additionally, a number of pilot schemes, which promoted the use of court-annexed mediation, were introduced both before and after the CPR was brought into force in $1999 .{ }^{119}$ The majority of these schemes were introduced in the County Courts. The schemes worked broadly in the same way as the original small claims arbitration had, although as each scheme was a local initiative they differed in exact practice. As explained by Prince, they were 'effectively time-limited mediation, administered by courts, but conducted by private mediators, who had been accredited and training by mediation organizations, approved by the court organizers of the scheme'. ${ }^{120}$ If the claim did not then settle, it would return to the court for adjudication. ${ }^{121}$ In 2005, the Department of Constitutional Affairs, having conducted a study of three such mediation schemes, replaced the local schemes with a national one.

The new, national, scheme had two features: first, a National Mediation Helpline (NMH); and secondly, a Small Claims Mediation Service (SCMS). The former provided 'a central resource, whereby parties and their representatives could be referred to a rota of mediators based throughout the country... Cases could be referred to the NMH by the courts, or via self-referral by contacting the NMH on a local rate telephone number'. ${ }^{122}$ The Civil Mediation Online Directory replaced it in 2011, ${ }^{123}$ albeit it provides the same basic service, i.e., referral to a private mediator. The one central difference between the online scheme and its predecessor is that the latter is self-referral only. ${ }^{124}$ The SCMS, which was introduced in 2007, provides a free mediation service for defended small claims. Mediators employed by Her Majesty's Courts and Tribunals Service, i.e., civil serv-

117. Woolf, above n. 99, at 102, 'The small claims procedure has been progressively refined over the 20 years since it was first introduced in 1973... The first scheme built on an existing statutory procedure which allowed a county court judge to refer cases to arbitration with the consent of the parties'.

118. Effected through the Civil Procedure Pre-Action Protocols and through CPR r.1.4(2)(e).

119. See Genn, above n. 13, at 97 (for a summary of the studies of the various schemes) and at 105-113; S. Prince, ADR after the CPR, in D. Dwyer (ed.), The Civil Procedure Rules Ten Years On (2009).

120. Ibid., at 330

121. Ibid.

122. Ibid.

123. See <http://www.civilmediation.justice.gov.uk> (last accessed, 15 November 2015).

124. See S. Blake, J. Browne \& S. Sime, The Jackson ADR Handbook (OUP) (2013), at 196-97 for an outline of the scheme. 
ants, carry out the mediations, a large number of which are conducted over the telephone. ${ }^{125}$ Within its first year of operation 7,725 small claims were referred to mediation. ${ }^{126}$ During 2010 and 2012 this had risen to more than $15,000^{127}$ referrals with a $73 \%$ settlement rate. $^{128}$

\subsection{Austerity's Effect on Simplified Process}

Increasing austerity could potentially have had a number of effects on both the small claims process and small claims mediation. The following sections consider two types of reform that have recently been introduced that could have been, but were not, a response to austerity. It also outlines one potential future reform that is, to a certain extent, predicated on the consequences of austerity.

\subsubsection{Increasing the Small Claims Limit and the Promotion of Small Claims Mediation}

The small claims limit has changed a number of times since its inception. It originally stood at $£_{,} 100$ in 1973 , rising to $£ 1,000$ in 1991 , and then to $£ 3,000$ in 1996. With the CPRs' introduction in 1999 it was increased to $f, 5,000 .{ }^{129}$ In 2013 the limit was increased to $f 10,000 .{ }^{130}$ In addition to this the small claims track's scope was widened. From its introduction in 1999 it had been possible for higher-value claims to be allocated to it with the consent of the parties. This provision was rarely used. In 2013 the requirement for party consent was removed, thus enabling the court to allocate suitable higher-value claims to the small claims track. ${ }^{131}$

The small claims mediation service has also been subject to post-austerity reform. In 2012 the CPR introduced a pilot scheme that provided for automatic referral for claims below $f, 5,000$ in value to the small claims mediation service; thus replicating the automatic referral to small claims arbitration that was in place prior to the Woolf reforms. ${ }^{132}$ As Blake et al. noted this did not transform the scheme into 'compulsory mediation'. It simply introduced a 'mandatory requirement to engage with a small claims mediator'. 133 The mediator, via a telephone conference, does no more than provide the parties with information about mediation and its benefits.

125. Ibid., at 193; Prince, above n. 122, at 334-39; Ministry of Justice, Solving Disputes in the County Courts: Creating a Simpler, Quicker and More Proportionate System, CP6/2011, at 43-44. By 2011 96\% of such mediations were conducted over the telephone.

126. Prince, above n. 119, at 335

127. Blake et al., above n. 124, at 193 citing Ministry of Justice, Solving Disputes in the County Courts: Creating a Simpler, Quicker and More Proportionate System - A Consultation on Reforming Civil Justice in England and Wales - The Government Response (CM 8274, 2012).

128. Ministry of Justice (CP6/2011), at 44 .

129. R. Scott (ed.), Civil Procedure (1999) (1999), at 260.

130. Civil Procedure (Amendment) Rules 2013, Art. 9 (SI 2013/262). The limit for personal injury claims remains, however, at its historic limit of $£ 1,000$.

131. CPR r.26.7(4) originally required party consent. This was revoked by Civil Procedure (Amendment) Rules 2013, Art. 8. The power to allocate high value claims to the small claims track is now governed solely by CPR r.26.7(3). See R. Jackson (ed.), Civil Procedure 2015 (2015), Vol. 1 at 26.7.1.

132. CPR PD 51H (The Mediation Service Pilot Scheme) (CPR PD 59th Update, 2012).

133. Blake et al., above n. 124, at 193, and see 194.
Should the parties choose to do so the mediator could then arrange to conduct a telephone-based mediation free of charge. No adverse consequences flow from a refusal to mediate. Following a further pilot scheme, which ran from 2013 to 2014, automatic referral of claims was formally introduced into the CPR in April 2014. ${ }^{134}$

Both the reforms to the small claims track and small claims mediation could have been necessitated by austerity. If, for instance, austerity had resulted in a reduction in judicial numbers, an increase in the use of mediation could have been promoted to produce a comparable reduction in the number of small claims, thereby easing what would otherwise have been increasing pressure on judicial workloads. Equally, it could have been promoted in the light of reductions in staffing levels in the court administration, again in order to reduce what would otherwise have been increasing workload pressure. Austerity has not, as yet, resulted in a reduction in judicial numbers. It has, however, resulted in a significant reduction in the number of court staff. ${ }^{135}$ That has been achieved through structural reforms to administrative processes such that, according to Her Majesty's Courts and Tribunals Service '...performance has been maintained...' ${ }^{136}$ While a decline in performance or an inability to maintain performance levels as a consequence of judicial and staff reductions could, in principle, have formed a basis for structural reform to the small claims track such that more claims were diverted to small claims mediation, the absence of any austerityinduced adverse effects on judicial numbers or administrative efficiency means they have not been an factor in reform.

Secondly, increasing the small claims limit and removing the need for party consent to allocate high value claims to the small claims track could have been effected if there had, for instance, been an increase in claims as a consequence of austerity. Increasing the number of claims dealt with on this track could have increased court efficiency, through ensuring that more claims are dealt with through its quicker, simplified process and through referral to mediation. Any increase in caseload caused by austerity could thus have been more readily dealt with, albeit at a cost to the quality of justice due to the more limited process available on the small claims track. Given the CPR's overriding objective, and its commitment to ensuring that all cases are dealt with justly whilst taking account of, amongst other things, the need to ration the courts' resources across all litigants, ${ }^{137}$ such a potential reduction in quality in order to promote effective resource use would not have been

134. See CPR PD51I (The Second Mediation Service Pilot Scheme) (CPR PD 61st Update, 2013) and CPR r.26.4A (as introduced in April 2014, Civil Procedure (Amendment) Rules 2014)

135. HM Courts \& Tribunals Service, Annual Report and Accounts 2012-2013, at 10, explained that 'The 2010 Spending Review (SR10) set a staff reduction target for HM Courts \& Tribunals Service of 2,980. This equates to circa $£ 107$ million saving in base line salaries per financial year from 2013-14.

136. Ibid., at 10

137. CPR r.1; J. Sorabji, English Civil Justice after Woolf and Jackson (2014). 
impermissible. On the contrary, it would have been consistent with the philosophical approach underpinning the CPR.

There was and is, however, no evidence to suggest an austerity-induced increase in litigation in general or small claims litigation in particular. On the contrary, the evidence shows that since 2007 there has been a reduction in small claims. By way of example, in 2007 the annual number of small claims that proceeded to trial was 53,248. This figure has declined in each subsequent year. By 2013 it stood at almost half the 2007 figure: 22,118. ${ }^{138}$ These figures are consistent with a general trend across civil litigation. Available government statistics show a consistent fall in new civil claims being issued and hearings over the period from 2007 to 2014. ${ }^{139}$ Given this it cannot properly be said that austerity could have created sufficient pressure, through increasing claiming rates to have required a reconsideration and reform of the small claims and small claims mediation procedures, to justify or require reform to enable greater diversion of higher level claims to those processes. ${ }^{140}$

While, as noted above, it is possible to envisage circumstances where austerity could have given rise to the present reforms to the small claims process, the actual impetus for both sets of reforms was independent of it. The initial recommendations for both reforms arose from a government consultation issued in 2011. Their aim was to simplify civil process, reduce the cost of litigation, and further embed the principle that litigation should be a course of last resort. ${ }^{141}$ The consultation formed one aspect of a wider reform agenda, which aimed to implement recommendations made by Sir Rupert Jackson's inquiry into the costs of English civil litigation from 2007 to $2009 .{ }^{142}$ That agenda understood, consistently with the Woolf reforms of the late 1990 s, the primary philosophy of the civil justice system to be the promotion of settlement. ${ }^{143}$ It also required the creation and effective operation of proportionate processes that matched the nature of the civil process to, primarily, the value of the claim so as to render the cost

138. See Court Statistics, Main Tables, available at: <https://www.gov.uk/ government/statistics/court-statistics-quarterly-april-to-june-2014> (last accessed, 15 November 2015).

139. Court Statistics show a consistent fall of new civil cases and hearings, see Ministry of Justice, Court Statistics Quarterly (January-March 2013), (April-June 2013), (July-September 2013), (October-December 2013), (January-March 2014), (April-June 2014). The figures for the 2013 periods are, respectively: a reduction against the equivalent period in 2007 of $26 \%$ and $38 \%, 26 \%$ and $38 \%, 26 \%$ and $41 \%, 12 \%$ and $37 \%$ (as against the same period in 2009). For the 2014 periods, the first saw an increase in both figures of $13 \%$ as against the final quarter in 2013, while the second saw a return to reduction in court work, with a $13 \%$ reduction in new cases and a $6 \%$ reduction in hearings as against the previous quarter.

140. For a similar analysis in respect of the United States, see R. Marcus, Procedure in a Time of Austerity, International Journal of Procedural Law (2013), at 133

141. Ministry of Justice (CP6/2011), at $34 \mathrm{ff}$

142. R. Jackson, Review of Civil Litigation Costs: Final Report (2009).

143. See, for instance, Woolf, above n. 99, at 5, endorsing the view that 'the philosophy of litigation should be primarily to encourage early settlement of disputes'. of litigation to litigants and the State proportionate to it. The impetus for reform was thus entirely separate from austerity.

The 2011 consultation first recommended the small claims track limit should increase to take account of inflationary changes in the value of money since 1999.144 As such it would bring claims that would in the past have been small claims but due to the operation of inflation now fell outside its financial limits back within the scope of the process. It also recommended that the limit increase in order to bring simple fast track claims that could readily be dealt with effectively on the small claims track to be brought within the latter's scope. This, it was argued, would increase access to the courts for small businesses, which would otherwise avoid litigation due to the costs regime applicable to the fast track. Such a reform would equally, it was argued, increase judicial efficiency thereby increasing the courts' ability to deal with claims more effectively. It was thus justified by the wider commitment to increasing access to justice through making available proportionate processes to a wider range of cases. In its response to the 2011 Consultation responses, the government confirmed that the inflationary and small business rationales were the two bases on which reform would be made. ${ }^{145}$ Austerity had not role to play.

The expansion of the small claims mediation scheme was also a product of the 2011 consultation. Again, its rationale was unconnected to austerity and pre-dated it. As the consultation made clear, the promotion of mediation, as a form of alternative dispute resolution, was central to the Woolf reforms and the CPR, i.e., it was a product of the $1990 \mathrm{~s}$ reform of civil justice. ${ }^{146}$ The expansion of small claims mediation was understood as one way in which that aim could be realised more fully than it had been between 1999 and 2011. This was to be achieved by making small claims mediation 'part of the actual court process' for the first time. ${ }^{147}$ The intention was to 'create a better environment within which settlement can be explored, with the help of a mediator, so that the parties do not have to proceed to what is often seen as a stressful final hearing'. ${ }^{148}$ This would enable all claims allocated to the small claims track, then 80,000 claims, to benefit from a mechanism that had produced highly satisfactory results for 30,000 individual litigants since it was introduced. ${ }^{149}$ Thus the aim was to better enable litigants to benefit from mediation.

Actual reform of the two processes may not have been predicated upon austerity, but there is one area of potential reform that is partially predicated on it. In 2015 the Civil Justice Council recommended reforms that, if implemented, would effectively replace both the small claims track and small claims mediation process

144. Ministry of Justice (CP6/2011), at 35.

145. Ministry of Justice (2012), at 4 and 11 .

146. Ministry of Justice (CP6/2011), at $39 \mathrm{ff}$.

147. Ibid., at 46 . The Ministry failing here to appreciate the arbitration-based origins of the small claims track.

148. Ibid., at 47

149. Ministry of Justice (2012), at 4 
with a new 'online court', which would deal with all low value claims. ${ }^{150}$ The new court would provide both an entirely digital, low cost, procedure that would provide online mediation, case management and, where necessary, adjudication. The central aim underpinning the proposal is to increase access to justice through making effective use of modern technology. It was, however, equally underpinned, by the aim of producing a 'lower cost court system'. ${ }^{151}$

Should such reforms be implemented and work as planned they would no doubt facilitate the achievement of the second aim. It would be expected to do so through eliminating the need for labour-intensive paper processes and the use of court buildings and hearing rooms. In turn this would facilitate a reduction in the number of administrative staff and judges; less work would need to be carried out by both through digitisation of previously paper-based processes, the increased use of automation in terms of procedural management of cases and through increasing the speed at which trials could be conducted. Equally, by increasing referrals to and use of mediation there would be an anticipated reduction in judicial workloads, facilitating a reduction in judicial numbers. As with the recommendations made by $\mathcal{F} u$ tice, noted above, it is as yet unclear to what extent this reform will be implemented. The scope for further reductions to the courts' budget in line with the need to reduce public spending over the long term, if the proposal is implemented, is however patent.

In summary, the evidence shows that while expansion of both the small claims track and mediation scheme could, in principle, have been driven by austerity either through a potential increase in claims or due to a reduction in resources to the courts neither of these reasons lay behind the reforms. Both were a further step in reforms of English civil procedure that began in the mid-1990s and were formally implemented via the CPR's introduction in 1999. This is not to say that any future expansion in either the small claims limit or the mediation scheme could not be predicated on austeritygrounds. That possibility cannot but exist, as the Civil Justice Council's proposals for the development of an online court demonstrate. It is, however, clear that austerity did not underpin this round of structural reform.

\section{Conclusion}

Milton Friedman once stated that '...only a crisis actual or perceived - produces real change. When the crisis occurs, the actions that are taken depend on the ideas lying around.' 152 The international financial crisis of 2007-2008 has every appearance of bearing this out in so far as the English civil justice system is concerned. It has produced a radical and continuing retrenchment of

150. Civil Justice Council, Online Dispute Resolution for Low Value Civil Claims (2015)

151. Ibid., at 5 .

152. M. Friedman cited in Blyth, above n. 1, at 103. public spending in the United Kingdom. ${ }^{153}$ This retrenchment is resulting in a degree of change, actual and probable, to the civil justice system that has not been seen since the 1870 s when the present system was put in place. ${ }^{154}$

One possibility for reform might have been to increase the availability of simplified forms of civil procedure beyond its established range, and beyond the level of its actual financial extension that was effected for reasons other than austerity. Use of the small claims track could, for instance, have been broadened out to higher value claims in order to provide both the parties and the court with a quicker, cheaper means to resolve them. Reforms introduced in 2013 provided for this. However, they were unrelated to austerity. Moreover, such reforms would not in any event meet the problems created by austerity. Expanding use of the small claims track, or small claims mediation, would not have met the real issue caused by austerity: reduction in civil legal aid and thereby legal representation and the consequence growth in individuals litigating in person. To revert to Friedman, the crisis for the civil justice system engendered by the financial crisis is one that has centred on its adversarial, lawyer-based, nature. Expanding the simplified process of the small claims track would not have met that problem despite its more inquisitorial, less lawyer-centric nature. It would not because the greater complexity of the claims affected by austerity and the reduction in civil legal aid it engendered renders them unsuitable for the small claims track and its simplified process or small claims mediation.

The question from Friedman then is which ideas that could tackle the difficulties that the courts were facing due to the increase in LiPs were lying around waiting to be developed? The answer is twofold. First, the general development of inquisitorial techniques across all civil litigation and the prospect, given reform proposals, of recasting the system in such a way that a new cadre of quasi-judicial Registrars carry out both a case management and inquisitorial, investigative function in all civil claims. Secondly, the arguably undesirable development of fee-paid McKenzie Friends as ersatz advocates.

These developments remain in their infancy. Use of a more inquisitorial or investigative procedure remains uncertain in scope and application. It remains unclear, for instance, how far a judge may go in inquiring into the facts through questioning witnesses. Given other recent innovations in civil procedure such as the use of concurrent expert evidence and the active role the court has in questioning expert witnesses, ${ }^{155}$ it is a reasonable assumption that having accepted a more inquisitorial role for one form of witness, there no longer remains a principled objection to a judge adopting a similar role in respect of lay witnesses where one or more parties are unrepresented. The inquisitorial fact-finding role may

\footnotetext{
153. Thomas, above n. 79 , at $9-10$

154. As a consequence of the 1873-1875 Judicature Acts, as noted in n. 153 , at $12-13$.

155. CPR PD 35.11
} 
thus develop considerably. Equally, developments surrounding the use of McKenzie Friends remain at an early stage. One possibility, if concerns about their use are acted upon, may see their ability to act as advocates restricted. Conversely, their ability to act as advocates could be tacitly or explicitly accepted and normalised. More broadly, and perhaps more radically, the promotion of fee-paid McKenzie Friends as advocates could lead to a fundamental restructuring, and removal, of the regulatory framework for the English legal profession in order to increase competition and thereby reduce the cost of legal services. If fee-paid McKenzie Friends do become a normal feature of the system, the argument that other providers of legal services require regulation beyond consumer protection law, for instance, of the application of the law of obligations, becomes more difficult to maintain. If we take these areas of reform together, the consequences of austerity can be seen to have already effected a fundamental shift in the English civil justice system and its procedure. To the extent that they have already engendered reform, it can rightly be described as 'real change', change that remains unfinished. 